\title{
South Sudan: Ethnicity and Statehood. Perceptions and the Way Forward
}

\author{
Timothy T. KULANG \\ Chidiebere, C. OGBONNA \\ Wotsuna KHAMALWA
}

\begin{abstract}
The purpose of this study was to examine the impact of ethnic conflicts on the statehood of South Sudan and to proffer remedial solution to end the conflicts. The study set-out to realize two objectives: to investigate the causes of ethnic conflict in South Sudan and to determine the strategic remedies to end ethnic conflict in South Sudan. The study adopted descriptive cross-sectional research design. A sample of 399

Timothy T. KULANG

Department of Development Studies,

Peace and Conflict

Kampala International University, Uganda

Chidiebere, C. OGBONNA

Department of Development Studies,

Peace and Conflict

Kampala International University, Uganda

E-mail: chidiebere.ogbonna@kiu.ac.ug

Wotsuna KHAMALWA

Department of Development Studies,

Peace and Conflict

Kampala International University, Uganda

Conflict Studies Quarterly

Issue 31, April 2020, pp. 41-55

DOI:10.24193/csq.31.3

Published First Online: 05/04/2020 respondents were selected from a target population of 5,734,057 using Slovene's formula. Data were collected through questionnaire. Validity and Reliability of the questionnaire were established using Content Validity Index (CVI) and Cronbach's alpha respectively. Results of the analyses on the first objective shows that the major causes of ethnic conflict in South Sudan are: unfair allocation of political positions, corruption and nepotism within the government system and power struggles among the elites. On the second objective, the study reveals that the remedies to ethnic conflict in South are, but not limited to: respect for minority rights and interest, fair allocation of state powers and national resources, a restructure of the modalities of coexistence through ethnic dialogue. Other remedial measures include: respect for ethnic communities' boundary, restructuring of state administrative organs into units that spread across the different regions and states, as well the labor force in these administrative units
\end{abstract}


should fairly represent the different ethnic affiliations within the country, full implementation of the 2018 Revitalized Peace Agreement (RPA) - particularly, the chapter two of the security arrangements that emphasizes Disarmament, Demobilization, and Reintegration (DDR).

Keywords: Ethnicity, Ethnic conflict, Ethnic division, South Sudan, Statehood.

\section{Introduction}

South Sudan is as of present the world's youngest state. As a new country, it is faced with the task of managing it numerous ethnic groups, uniting them to forge ahead as one nation (. However, this anticipated reality did not materialize, instead the country slipped into a violent conflict that has manifested adverse consequences on the country's functionality as an independent state. Since December 2013, barely two years after gaining independence from the Republic of Sudan, violent conflict erupted in South Sudan (Sandu, 2014b). According to the New York Times, an estimated 383,000 people have died as a result of the conflict (Specia, 2018). A similar report published by the London School of Hygiene and Tropical Medicine indicates that about half of the casualties resulted from fighting between ethnic rivals as the conflict spread across the country, and the other half died from disease, hunger and other causes exacerbated by the ongoing civil war (Checchi, Testa, Warsame, Quach, \& Burns, 2018).

The impact of the conflict can be felt from all spheres of the economy. Since about $98 \%$ of government revenue comes from oil (Cust and Harding, 2013; Shankleman, 2011, Sandu, 2012, 2014a), the decline in oil production resulting from the war has affected the overall economic situation in the country, coupled with the decrease in the global oil prize. The economy has been ravaged by inflation as South Sudanese Pound lost around $90 \%$ of its value following the 2015 liberalization of exchange rates that saw the country lose ground against other global currencies (Sudan Tribune, 2017). In 2016 inflation surpassed the $550 \%$ increase rate leaving the government with over $\$ 1.1$ billion deficit in the 2016-2017 financial year (IMF, 2017). Also, wages were significantly reduced while the prices of even the most basic products skyrocketed - inflicting more suffering on the people. For example, the price of flour, sorghum and rice had increased by about $400 \%$ since the beginning of the conflict (Famine Early Warning Systems Network, 2016).

In 2018, the International Monetary Fund (IMF) warned that if the war prolongs, it will lead to a complete collapse of the South Sudanese economy because it will acutely impact on economic imbalances and will definitely exhaust economic buffers and consequently collapse the economy (Sudan Tribune, 2016). Despite all the negative assessments of the conflict, its main cause(s) still remain an issue of debate, however the most profound reason advanced by scholars such as (Nyadera, 2018; Radon and Logan, 2014; 
Schomerus and Mareike, 2017) is that the conflict is caused by ethnic divisions within the South Sudanese society.

Observably, South Sudanese are yet to embrace national identity; people clinch more to their ethnic identities than the national identity. In fact, there is no one collective definition that unites the heterogeneous people of South Sudan, each and every one prefers to identify him/herself with the ethnic group he/she belongs and this perhaps presents a challenge to national unity and statehood. Another considerable issue is common language. The country's constitution specified English as the first language and Arabic as the second language, however, due to high illiteracy level, a huge proportion of the citizens are unable to communicate in these languages. According to UNESCO (2019) report, South Sudan has 27\% literacy rate, which implies that $73 \%$ of the population are illiterate - unable to read and write. Consequently, a significant portion of the population communicates in their local language and thus, relate only with people of their ethnicity and shared language. It is estimated that the 60 ethnic groups in South Sudan speaks different local languages, making it difficult for people of different ethnical background to relate and identify as one. The implication being that in South Sudan people minimally relate with people from a different ethnic group other than theirs, which seem to present a challenge to the country's statehood.

\section{Theoretical Framework}

The study was guided by Elite Manipulation Theory. The theory is part of the "classic" elite theories that were formulated at the end of the nineteenth century and in the first decades of the twentieth century based on Max Weber's ideas, especially concerning the centrality of political power and charismatic leadership. The theory contends that the elites utilizes ethnic violence as a purposeful and rational strategy to acquire or maintain political power. In doing this, the elites intentionally instigate ethnic violence as a way of gaining political support (Fearon and Laitin, 2000; Gagnon, 1994).

According to Snyder (2001), one of the key reasons for the increased risk of nationalist conflict during democratization is the systematic use of ethnic divisions for political gain. In societies with strong ethnic identities, ethnic entrepreneurs or elites usually capitalize on already existing ethnic divisions within the society to pursue personal political gain and private interests (Sambanis, 2001). In some cases, the elites construct ethnic identities in order to have large enough voting blocs or "minimum winning coalitions" (Bates, 1983; Munene, 2010; Lynch, 2011). The theory argues that political power is held by a relatively small and wealthy group of people sharing similar values and interests. Furthermore, it holds that ethnic conflicts are elite driven clashes and controversies, while it stresses the role of political elites and their ability to incite the masses to violence. 
The theory clearly fits into the present situation in South Sudan, particularly the ongoing civil war that is fought along ethnic lines. The civil war in South Sudan is fought along ethnic lines of the Dinka and Nuer, however the conflict emanated from a personal discord between the leaders. A personal misunderstanding between President Salva Kiir and his former vice Riek Marchar is at the root of the conflict. These two elites, however managed to manipulate personal grievances to escalate tribal sentiments and conflict. Thus, the political interest and survival of these two elites is at the core of a civil war that has devastated the entire country, with an attendant impact on the neighboring countries. Thus, the theory offers a multidimensional and substantial framework to analyze key issues related to ethnicity and ethnic conflicts. According to Elite Manipulation Theory, the concern of the elites is to define the interest of the collective in a way that coincides with their own power interests. In doing so, they express their interests in the language of the collective interest, drawing support and sympathy from unsuspecting public.

\section{Methodology}

The study adopted descriptive cross-sectional research design. Data collection involved the use of survey questionnaire. The target population consisted of the adult population (people above the age of 18) of South Sudan, which is 5,734,057 from the three regions of Equatoria, Bahr el Gazal and Upper Nile Region. The sample size of the study was 399 respondents determined using Slovene's formula as shown below.

$$
n=\frac{N}{1+N(\alpha)^{2}}
$$

Where: $n=$ the required sample size,

$N=$ the known population size,

$\alpha=$ the level of significance, which is fixed at $=0.05$.

$$
\mathrm{n}=\frac{5,734,057}{1+5,734,057(0.05)^{2}}=399
$$

Table1: Sample Size of the Study

\begin{tabular}{lccc}
\hline \multicolumn{1}{c}{ Region } & Population & Sample Size & Sampling Technique \\
\hline Greater Bahr el Gazal & $1,856,400$ & 135 & Simple Random Sampling \\
Greater Upper Nile & $2,179,285$ & 152 & Simple Random Sampling \\
Greater Equatoria & $1,698,372$ & 112 & Simple Random Sampling \\
\hline \multicolumn{1}{c}{ Total } & $5,734,057$ & 399 & \\
\hline
\end{tabular}

Source: Author's primary data, 2018 


\section{Validity}

Brown (1996) defines validity as the degree to which an instrument measures what it claims, or purports, to be measuring. Validity of the instrument involved two processes: face validity and content validity. Face validity involved the expert scoring relevance of questions in the instrument in relation to the study variables, while content validity involved calculating the Content Validity Index (CVI) as shown below. CVI of more than 0.7 implies that the instrument is valid.

$$
\begin{gathered}
\mathrm{CVI}=\frac{\text { Number of Items declared } \text { Valid by the judges }}{\text { Total number of items in the instrument }} \\
\text { CVI }=\frac{30}{30}=0.94
\end{gathered}
$$

Since the Content Validity Index was $0.94>0.7$ then it means that the instrument (questionnaire)is valid to measure what it was intended to.

\section{Reliability}

The test-retest and Cronbach's alpha methods were adopted to evaluate reliability of the research instrument. The test-retest reliability method examines the extent to which a measure, procedure or instrument yields the same result on repeated trials (Ebuoh, 2017). This was done by administering the research instrument twice on the same set of respondents at different times. The questionnaire was given to 40 respondents at the outset, and the same instrument was re-administered to the same respondents after two weeks. Data collected from the two intervals were correlated. The result of Pearson's linear correlation coefficients (PLCCr) shows a reliability coefficient of 0.81 . This indicates that the instrument was reliable for the study. An instrument is considered reliable when it has a coefficient ranging from 0.60-0.99.

The Cronbach's Where: $\alpha=$ Alpha coefficient

$$
\begin{aligned}
& K=\text { Number of items in the instrument } \\
& \sum=\text { Sum } \\
& S D_{i}^{2}=\text { Individual item variance } \\
& S D_{t}^{2}=\text { Variance of total score }
\end{aligned}
$$

Alpha Coefficient was used to estimate the reliability of the instruments using SPSS 20.0. Upon performing the test, the values that were 0.7 and above were regarded as reliable. In the case of psychometric tests, they must fall within the range of 0.7 and above for the test to be reliable (Creswell, 2009). The formula below was applied to test the reliability of instruments:

$$
\alpha=\frac{K}{K-1}\left(\frac{1-\sum S D_{i}^{2}}{S D_{t}^{2}}\right)
$$


Table 2: Results of the Cronbach's Alpha Reliability Coefficient for Likert-type Scale test for Questionnaire

\begin{tabular}{lcc}
\hline \multicolumn{1}{c}{ Variable } & Number of items & Alpha \\
\hline Causes of ethnic conflicts in South Sudan & 22 & 0.843 \\
Strategies to end ethnic conflicts in South Sudan & 10 & 0.773 \\
Average & $\mathbf{3 2}$ & $\mathbf{0 . 8 0 8}$ \\
\hline
\end{tabular}

As can be seen in the results of the reliability tests presented in Table 2, the Cronbach's alpha coefficient is 0.81 , and indicates that the instrument is very reliable. Hence, both the test retest and Cronbach's alpha tests show that the instrument is very reliable.

\section{Mean Range and Standard Error Analysis}

Descriptive statistics (mean scores and standard deviation) were used to answer the following research questions: what are the causes of ethnic conflict in South Sudan? and what are the strategic remedies to end the ethnic conflict in South Sudan? The researcher employed the weights attached to the scale to compute the mean scores for the items as well as for all the items of the questionnaire. For the research questions, real limit of numbers displayed in Table 3, were used in analyzing the data and answering the research questions. Any items with a mean of $3.00-3.99$ and above was considered accepted, otherwise it was considered rejected. The Standard Error (SE) coefficient was used to verify the reliability of descriptive statistics. The decision rule is to accept descriptive analysis as better and more reliable if the SE coefficient is close to zero $(0)$.

Table 3: Mean Range Analysis

\begin{tabular}{lll}
\hline \multicolumn{1}{c}{ Mean Range } & Respondents & Interpretation \\
\hline $4.0-5.00$ & Agree & Accepted \\
$3.0-3.99$ & Strongly Agree & Totally accepted \\
$2.5-2.99$ & Undecided & No opinion \\
$1.5-2.49$ & Disagree & Rejected \\
$1.00-1.49$ & Strongly disagree & Totally rejected \\
\hline
\end{tabular}

\section{Preliminary Analysis for Empirical Results Response Rate}

The response rate is the percentage of people who responded to the study, and was calculated using the formula:

$$
\frac{\text { Actua } \ln \text { umberofres ponses }}{T \text { arg etedresponses }} \times 100 \%=91.75 \%
$$


If the response rate is $50 \%$ or less, it shows that the data is inadequate for analysis, but if the response rate is $60 \%$, it indicates that the data is good for analysis. If the rate is $70 \%$ and above, then the data is very good for analysis. The researcher should use all means to increase the response rate in order to have a representative sample for meaningful generalization (Mugenda and Mugenda, 2003). Out of the 399 distributed questionnaires, a total of 385 were retrieved, 13 were partially filled, while 5 were vaguely filled, hence, the study relied on 367 completely filled questionnaires for analysis and reaching conclusions on findings. The response rate is good enough and in line with Richardson and St. Pierre (2005) who argues that response rates of 60 percent or more are regarded acceptable for social science studies. Based on these assertions, this implies that the response rate for this research was adequate for analysis.

\section{Objective-based Analyses}

Analysis is presented according to the study objectives, which are: Causes of ethnic conflict in South Sudan and the strategic remedies to end ethnic conflict in South Sudan.

\section{Causes of ethnic conflicts in South Sudan}

This section presents the results of the mean ratings and standard deviations of the responses obtained from respondents using questionnaires. The section aims at providing answer to research question one: what the causes of ethnic conflict in South Sudan? The summary of the responses is presented in Table 4. below.

Table 4. above presents results of the mean ratings and standard deviations of responses from the respondents. Notice that the mean ratings of responses from the respondents for items 1 to 22 are: $4.1(0.06), 4.3(0.03), 4.1(0.04), 4.4(0.06), 4.3(0.06), 3.8(0.04)$, 3.8 (0.04), 4.2 (0.04), $4.2(0.04), 4.2$ (0.03), $4.2(0.04), 4.0(0.05), 3.8(0.05), 3.9(0.04)$, 4.0 (0.04), 3.7 (0.05), $4.1(0.04), 4.0(0.05), 4.0(0.04), 4.2(0.04)$, and $4.1(0.04)$; with corresponding standard deviations of $1.19,0.66,0.85,0.70,1.21,1.15,0.79,0.79,0.81$, $0.78,0.75,0.86,1.11,0.98,0,91,0.94,1.09,0.84,1.00,0.87$, and 0.94 .

Based on the cut-off point of 4.00, the respondents rated items 1, 2, 3, 4, 5, 8, 9, 10,11, $12,13,16,18,19,20,21$ and 22 totally accepted. These indicate that the respondents totally accepted that unequal distribution of the money that come from the sale of oil, corruption and nepotism within the government system, poverty, unfair allocation of political positions and power struggles among the elites are among the causes of ethnic conflict in South Sudan. The respondents also totally accepted that primitivism and ignorance among the ethnic groups, lack of awareness about the negative consequences of conflicts, bureaucratic leadership style practiced by the leaders, lack of competent leaders to deal with the situation, selfishness and ethnocentric policies and competition over the scare resources is among the causes of ethnic conflict in South Sudan. The respondents further totally accepted that ethnic groupings such as its history, traditions, 
Table 4: Mean Ratings and Standard Deviations on Causes of Ethnic Conflict in South Sudan

Descriptive Statistics

\begin{tabular}{|c|c|c|c|c|}
\hline & $\mathbf{N}$ & & ean & $\begin{array}{c}\text { Std. } \\
\text { Deviation }\end{array}$ \\
\hline & Statistic & Statistic & Std. Error & Statistic \\
\hline $\begin{array}{l}\text { An unequal distribution of the money } \\
\text { that come from the sale of oil }\end{array}$ & 367 & 4.1935 & .06218 & 1.19111 \\
\hline $\begin{array}{l}\text { Corruption and nepotism within } \\
\text { the government system }\end{array}$ & 367 & 4.3597 & .03478 & .66637 \\
\hline Poverty as a major cause of the conflict & 367 & 4.1662 & .04474 & .85708 \\
\hline Unfair allocation of political positions & 367 & 4.4251 & .03698 & .70844 \\
\hline Power struggles among the elites & 367 & 4.3297 & .04112 & .78772 \\
\hline Differences in Religion religions and beliefs & 367 & 3.8529 & .06364 & 1.21922 \\
\hline $\begin{array}{l}\text { Different tribes that are living } \\
\text { in South Sudan are the problem }\end{array}$ & 367 & 3.8392 & .06037 & 1.15649 \\
\hline $\begin{array}{l}\text { Primitivism and ignorance } \\
\text { among the ethnic groups }\end{array}$ & 367 & 4.2098 & .04128 & .79073 \\
\hline $\begin{array}{l}\text { Lack of awareness about the negative } \\
\text { consequences of conflicts }\end{array}$ & 367 & 4.2125 & .04151 & .79517 \\
\hline $\begin{array}{l}\text { Bureaucratic leadership style } \\
\text { practiced by the leaders }\end{array}$ & 367 & 4.2125 & .04240 & .81217 \\
\hline $\begin{array}{l}\text { Lack of competent leaders } \\
\text { to deal with the situation }\end{array}$ & 367 & 4.2752 & .04095 & .78442 \\
\hline Selfishness and ethnocentric policies & 367 & 4.2507 & .03963 & .75917 \\
\hline Competition over the Scare resources & 367 & 4.0981 & .04537 & .86913 \\
\hline Conflicts caused by the colonial regimes & 367 & 3.8965 & .05801 & 1.11137 \\
\hline Main cause lies on cultural beliefs & 367 & 3.9482 & .05134 & .98349 \\
\hline $\begin{array}{l}\text { Ethnic groupings such as its history, } \\
\text { traditions, and customs }\end{array}$ & 367 & 4.0954 & .04786 & .91685 \\
\hline $\begin{array}{l}\text { Meeting and getting to know people from } \\
\text { ethnic groups other than their own }\end{array}$ & 367 & 3.9619 & .04907 & .94010 \\
\hline $\begin{array}{l}\text { Would be better if different ethnic groups } \\
\text { didn't try to mix together }\end{array}$ & 367 & 3.7766 & .05734 & 1.09853 \\
\hline $\begin{array}{l}\text { Having alot of pride in their ethnic group } \\
\text { and its accomplishments }\end{array}$ & 367 & 4.1826 & .04389 & .84084 \\
\hline $\begin{array}{l}\text { Association with people from other } \\
\text { ethnic groups can be suspicious }\end{array}$ & 367 & 4.0518 & .05234 & 1.00275 \\
\hline $\begin{array}{l}\text { Feeling good about their cultural } \\
\text { or ethnic background }\end{array}$ & 367 & 4.2207 & .04559 & .87329 \\
\hline $\begin{array}{l}\text { Having a strong commitment to improve } \\
\text { life in their ethnic community }\end{array}$ & 367 & 4.1172 & .04926 & .94372 \\
\hline Valid N (listwise) & 367 & & & \\
\hline Average & & 4.1216 & 0.0477 & 0.9140 \\
\hline
\end{tabular}


and customs, pride in their ethnic group and its accomplishments, cultural or ethnic background and strong commitment to improve life in their ethnic community are among the causes of ethnic conflict in South Sudan. Observe however, that the respondents rated item 4 as the highest cause of ethnic conflicts in South Sudan, followed by items 2 and 5. These ratings suggest that the highest causes of ethnic conflict in South Sudan are unfair allocation of political positions, corruption and nepotism within the government system and power struggles among the elites.

Based on the cut-off point of 3.00-3.99, the respondents rated items 6, 7, 14, 15, and 17 acceptable. These indicate that the respondents accepted that differences in religion and belief, differences in tribe, conflicts caused by the colonial regimes and absence of viable ethnic interaction groups other than their own are the causes of ethnic conflict in South Sudan. Although, all the respondents rated the items as acceptable, item 17 is the least cause of ethnic conflict in South Sudan. Thus, absence of viable ethnic interaction groups other than their own is the least causes of ethnic conflict in South Sudan.

The cluster or average mean rating of responses of the respondents on the causes of ethnic conflict in South Sudan is 4.12 with an average standard deviation of 0.91 . This implies that the causes outlined above are among the major causes of ethnic conflicts in South Sudan. The standard errors for all the 22 mean ratings are within the conventional significance levels in humanities and social sciences. More so, the standard error for the cluster of average mean is 0.04 , which is less than the $5 \%$ significance level. This indicates that the descriptive analysis is very reliable for policy-making purposes.

\section{Strategic Remedies to end Ethnic Conflict in South Sudan}

This section displays the results of the mean ratings and standard deviations of the responses obtained from respondents on the strategic remedies to end of ethnic conflict in South Sudan. The summary of the responses is presented in Table 5. below.

Notice from Table 5 . that the mean ratings of responses from the respondents for items 1 to 10 are: 4.6 (0.03), 4.3 (0.03), 4.4 (0.03), $4.4(0.03), 4.4$ (0.03), 4.4 (0.03), 4.1 (0.04), $4.3(0.03), 4.3(0.04)$, and $4.2(0.05)$; with corresponding standard deviations of 0.58 , $0.63,0.58,0.67,0.65,0.67,0.88,0.70,0.77$, and 0.97 .

Based on the cut-off point of 4.00, the respondents rated items 1, 2, 3, 4, 5, 6, 7, 8, 9, and 10 totally accepted. These suggest that the respondents totally acceptable that respect each other's sovereignty and take the overall situation and their long-term interests into consideration, political stability and accepted form of governance by all South Sudanese, respect for ethnic communities' boundary, fair allocation of national resources, and carrying out friendly cooperation, are among the possible solutions to ethnic conflict in South Sudan. The respondents also totally accepted that dialogue among the ethnic communities, re-division of South Sudan into new administrative units on new basis, 
Table 5: Mean Ratings and Standard Deviations of Responses on Strategic Remedies to End Ethnic Conflict in South Sudan

Descriptive Statistics

\begin{tabular}{|c|c|c|c|c|}
\hline & $\mathbf{N}$ & & ean & $\begin{array}{c}\text { Std. } \\
\text { Deviation }\end{array}$ \\
\hline & Statistic & Statistic & Std. Error & Statistic \\
\hline $\begin{array}{l}\text { Respect for ethnic nationalities' rights and } \\
\text { consideration of their long-term interests } \\
\text { in the South Sudan state }\end{array}$ & 367 & 4.6076 & .03057 & .58557 \\
\hline $\begin{array}{l}\text { Political stability and accepted form } \\
\text { of governance by all South Sudanese }\end{array}$ & 367 & 4.3079 & .03299 & .63204 \\
\hline Respect ethnic communities' boundary & 367 & 4.4005 & .03040 & .58234 \\
\hline Fair allocation of national resources & 367 & 4.4850 & .03512 & .67279 \\
\hline Carrying out friendly cooperation & 367 & 4.4142 & .03419 & .65505 \\
\hline $\begin{array}{l}\text { Enhancing communities dialogue can be } \\
\text { good tool to resolve the local conflicts }\end{array}$ & 367 & 4.3924 & .03531 & .67650 \\
\hline $\begin{array}{l}\text { Redivision of South Sudan into new } \\
\text { administration units on new basis }\end{array}$ & 367 & 4.1008 & .04641 & .88902 \\
\hline $\begin{array}{l}\text { Full implementation } \\
\text { of the } 2015 \text { peace agreement }\end{array}$ & 367 & 4.3134 & .03670 & .70316 \\
\hline Elimination of the culture of impunity & 367 & 4.3106 & .04052 & .77634 \\
\hline $\begin{array}{l}\text { Control of Information technology as a } \\
\text { mechanism for the spread of conflict } \\
\text { to all parts of South Sudan }\end{array}$ & 367 & 4.2480 & .05093 & .97571 \\
\hline Valid N (listwise) & 367 & & & \\
\hline Average & & 4.3580 & 0.0373 & 0.7148 \\
\hline
\end{tabular}

full implementation of the 2015 revitalized peace agreement, elimination of the culture of impunity and control of information technology as a mechanism for the spread of conflict to all parts of South Sudan as possible solutions to end ethnic conflict in South Sudan. Notice also from Table 5, that the respondents rated item 1 as the highest possible remedial measure to end ethnic conflicts in South Sudan, followed by items 4 and 6. These ratings suggest that the most likely possible solution to end ethnic conflict in South Sudan are respect for ethnic nationalities' rights and consideration of their longterm interests in the South Sudan state affairs, fair allocation of national resources and enhancing communities dialogue can be a good tool to resolve the local conflicts which will result into resolution of the national conflict. However, the respondents rated item 7 the least possible solution to end ethnic conflict in South Sudan. Thus, re-division of South Sudan into new administration units on new basis is the least possible solution to end ethnic conflict in South Sudan. 
The cluster or average mean rating of responses of the respondents on the possible solution to end ethnic conflict in South Sudan is 4.35 with an average standard deviation of 0.71. This indicates that the possible solutions end ethnic conflicts in South Sudan are among those presented in Table 5. The standard errors for all the 10 mean ratings are within the conventional significance levels in humanities and social sciences. More so, the standard error for the cluster of average mean is 0.03 , which is also less than the $5 \%$ significance level. This indicates that the descriptive analysis is reliable for policy-making purposes.

\section{Conclusions}

The study concludes that ethnicity does not pose any direct challenge to statehood in South Sudan, rather ethnic loyalty presents some challenges. When people are more concerned with the welfare and ideology of their ethnic affiliation against the interest of other ethnic nationalities in a multi-ethnic society, the consequent denial of access to resources and other forms of marginalization endured by the other ethnic groups often result in violent engagement and eventually lead to Protracted Social Conflict. Thus, the study disagrees with the assumption that multi-ethnicity is a source of violent conflict. Although, it is a fact that when inter-ethnic division, sentiment and hatred are inflamed, they may lead to violent confrontation, but that does not mean that violent conflict is inevitable in multi-ethnic settings. In fact, the study holds that inter-ethnic conflicts can be avoided through respect for human rights, effective legislation that protects minority rights and interest, and a democratic and representative political system that acknowledges diversity,can increase the chances of a peaceful multi-ethnic coexistence.

\section{Recommendations}

The study provided recommendation on the key objectives that guided the study. On the first objective, causes of ethnic conflict in South Sudan, the study recommends that the government of South Sudan should establish a Justice and Reconciliation Panel (JRP) with the goal of enhancing justice, forgiveness, healing and reintegration of the offenders and the offended. This is very important considering the magnitude of atrocities committed against the population since the beginning of the ongoing civil war. The recommended panel will constitute of South Sudan citizens of different social-economic status. Thus, the JRP is expected to adopt the model of the Gacaca Court in Rwanda, where the judges and facilitators of justice and reconciliation comprised of ordinary and everyday Rwandese, even those without formal legal education. The JRP will address the atrocities committed against the citizens of South Sudan since the beginning of the civil war with a focus on providing an environment for acceptance of guilt, punishment, forgiveness, healing and reconciliation. Thus, the panel will emphasize restorative, rather than retributive justice. 
Secondly, there should be a full restructuring of the governance system. The recommendation here is government of South Sudan must create affirmative action packages for disadvantaged (minority) groups, which will emphasize the "management of diversity". Accordingly, the structure of governance should be constitutionally reviewed to make way for a government of national unity through power sharing mechanisms that appreciates proportionality rather than "survival of the fittest". Fair ethnic representation in state affairs is therefore the key to dowsing discontent and grievances. The study believes that a genuine South Sudan that will be appreciated by its citizens would likely emerge through an "all-inclusive" government.

Thirdly, there is need for decentralization and restructuring of the governance process in South Sudan. The dynamics of the ongoing civil war shows that there is need to decentralize governance and restructure the governance system. In doing so, the starting point is to limit the powers and responsibilities of the federal government through regional decentralization. In this case, the three existing regions should be formally constituted as regional governments with part of the powers and recourses currently held by the federal government conceded to them. The regional governments, will then develop their own constitution, albeit deriving terms of reference from the national constitution, but will be accorded powers to decide how and through what structures to deliver governance at the local level. With regional governments in place, conflicts will be likely curtailed at regional levels with less possibility to attain the status of a national crisis in terms of spreading to engulf the entire nation. The logic here is that as long as the pockets of instability do not occur simultaneously within the regions, they will constitute little or no overall threat to national peace and stability.

On the second objective,the strategic remedies to end ethnic conflict in South Sudan the study recommends first that the government should initiate a mass 'national youth skill acquisition program', where the government will facilitate training of youths on skill acquisition and thereafter provide business start capital for the trainees. It is believed that engaging the youths in gainful businesses and other economic activities will definitely douse their attraction to violence, as their economic status improves.

Another, factor that sustains ethnic loyalty is illiteracy, therefore the study recommends that the government of South Sudan should make education a priority. The country occupies an unenviable position on world education ranking and therefore the government should pursue a mass education policy that will address the educational needs of both the young and older generations. It is important to note that the government merely pursing a mass free education program will not be a solution, instead education should be made attractive to the population particularly to parents. One way of doing this is to provide free education that will include free educational materials for pupils. Then, the government through the district/ local council should establish a reward package for parents whose child(ren) are registered in school. For example, parents can be 
rewarded with a goat or cow if their child(ren) did not miss school for the whole term or academic year. That alone will be enough encouragement for parents to ensure that their children attend school regularly. Also, there could be provision for stipend for parents to cover the income their children would have brought home if they chose to go to work or hunt instead of going to school. The logic here is that a significant improvement in the literacy level, particularly among the youths of South Sudan, will liberate them from the shackles and grip of manipulation by the elites, which apparently fuels ethnic sentiment and loyalty.

Finally, the government of South Sudan should convene a "Sovereign National Conference of Ethnic Nationalities", where all the ethnic groups will be fairly represented and with a mandate to develop a blueprint on how best the country can move forward peacefully. The idea here is that a National Conference will provide a forum where all ethnic groups and nationalities can express their grievances and offer ideas on how to restructure the country. This forum will provide the opportunity for different ethnic groups to seat together and reach a consensus on resources allocation, power sharing, how rights will be protected and how a peaceful and democratic South Sudan can be attained.

Finally, it is important to note that although the above recommendations are limited to internal actions and capacity, it does not mean that inputs from regional and international actors cannot help South Sudan to move forward, instead the consideration here is that foreigners cannot determine the pace and shape of urgent measures to work on a constitutional review, land ownership and boundary demarcation, resources management, forgiveness and healing. The argument is that South Sudan's present challenge can only be resolved through a national dialogue and consensus agreement that emanates from the people, and which takes into consideration the interest and concerns of the different ethnic nationalities in the country.

\section{References}

1. Bates, R. H. (1983). Modernization, Ethnic Competition, and the Rationality of Politics in Contemporary Africa. In D. Rothchild and V. A. Olunsorola (eds.), State versus Ethnic Claims: African Policy Dilemmas (pp. 152-171). Boulder, CO: Westview Press.

2. Brown, G. K. (2008). Decentralisation and Conflict: Introduction and Overview. Conflict, Security and Development, Vol. 8, No. 4, pp. 387-392.

3. Checchi, F., Testa, A., Warsame, A., Quach, L., \& Burns, R. (2018). Estimates of Crisis-Attributable Mortality in South Sudan, December 2013- April 2018: A statistical analysis. London School of Hygiene and Tropical Medicine. Retrieved from https://www.lshtm. ac.uk/south-sudan-full-report.

4. Creswell, J. (2009). Research Design: Qualitative, Quantitative, and Mixed Methods Approaches (3rd eds.), Thousand Oaks, CA: Sage Publications.

5. Cust, J. \& Harding, T. (2013). Oil in South Sudan Implications from International Experience,Working Paper, International Growth Centre. Available at: https://www. 
theigc.org/wp-content/uploads/2014/09/Cust-Harding-2013-Working-Paper.pdf (Accessed 13/05/2019).

6. Ebuoh, C. N. (2017). Criterion Related Validity as a Correlate of Students' Reliability in Biology Essay Tests. International Technology Research Journal, 5(1), 83-91.

7. Famine Early Warning Systems Network (2016, April 16). Food security outlook update: Staple food prices increasing more rapidly than expected. Retrieved from http:// fews.net/east-Africa/south-Sudan/food-security-outlook-update/April-2016.

8. Fearon, J.D. \& Laitin, D.D. (2000). Violence and the Social Construction of Ethnic Identity. International Organization, 54(4), 845-877.

9. Gagnon, V.P. (1994 - 5). Ethnic Nationalism and International Conflict: The Case of Serbia. International Security, 19(3), 130-166.

10. International Monetary Fund (2017, March 23). South Sudan: 2016 Article IV Consultation-Press Release; Staff Report; and Statement by the Executive Director for South Sudan. IMF Staff Country Report No. 17/73. Washington: IMF.

11. Lynch, G. (2011). I Say to You: Ethnic Politics and the Kalenjin in Kenya. Chicago and London: University of Chicago Press.

12. Mugenda, O. M. \& Mugenda, A. G. (2003). Research methods: Quantitative and qualitative Approaches. Nairobi: African Centre for Technology Studies

13. Munene, K. (2010). Production of Ethnic Identity in Kenya. In K. Njogu and K. Ngeta (eds.), Ethnic Diversity in Eastern Africa: Opportunities and Challenges, pp. 41-54. Nairobi: Twaweza Communication.

14. Nyadera, I. N. (2018). South Sudan Conflict from 2013 to 2018: Rethinking the Causes, Situation and Solutions. African Journal on Conflict Resolution. Available at: https:// www.accord.org.za/ajcr-issues/south-sudan-conflict-from-2013-to-2018/ (Accessed 03/10/2018).

15. Radon, J. \& Logan, S. (2014). South Sudan: Governance Arrangements, War, and Peace. Journal of International Affairs, 68(1), 149-167.

16. Richardson, L. \& St. Pierre, E. A. (2005). Writing: A Method of Inquiry. In N. K. Denzin and Y. S. Lincoln (eds.), The Sage Handbook of Qualitative Research, pp. 959-978. Thousand Oaks, CA: Sage Publications.

17. Sambanis, N. (2001). Do Ethnic and Non-ethnic Civil Wars Have the Same Causes?. Washington DC: World Bank.

18. Sandu, C. (2012). Sudan vs. Sudan: Conflict, peace and oil. Conflict Studies Quarterly, 1, 67-86.

19. Sandu, C. (2014a). The two Sudans: Old and New Friends and Enemies. Conflict Studies Quarterly, 6, 63-78.

20. Sandu, C. (2014b). The South Sudan Coup: A political rivalry that turned ethnic. Conflict Studies Quarterly, 7, 49-65.

21. Schomerus, V. \& Mareike, L. (2017). South Sudan's Civil War Will Not End with a Peace Deal. Peace Review, 29(3), 333-340.

22. Shankleman, J. (2011). Oil and State Building in South Sudan, New Country, Old Industry. Washington: The United States Institute of Peace. 
23. Specia, M. (2018). 383,000: Estimated Death Toll in South Sudan's War. The New York Times, September 26. Available at: https://www.nytimes.com/2018/09/26/world/af rica/south-sudan-civil-war-deaths.html (Accessed 23/05/2019).

24. Snyder, J. (2001). From Voting to Violence: Democratization and Nationalist Conflict, New York: W.W. Norton.

25. Sudan Tribune (2016). IMF Warns of Further Deteriorating Economy in South Sudan, 3 June. Available at: <http://www.sudantribune.com/spip.php?article59164>? (Accessed 23/03/2019).

26. Sudan Tribune (2017). South Sudanese Pound Loses Further Value Against U.S. Dollar, 13 April. Available at: <http://www.sudantribune.com/spip.php?article62178> (Accessed 23/03/2019).

27. UNESCO (2019). UNESCO Country Strategy for the Republic of South Sudan. Available at: http://www.unesco.org/new/fileadmin/MULTIMEDIA/FIELD/juba/pdf/UCS_ 2019_2021.pdf (Accessed 04/04/2019). 